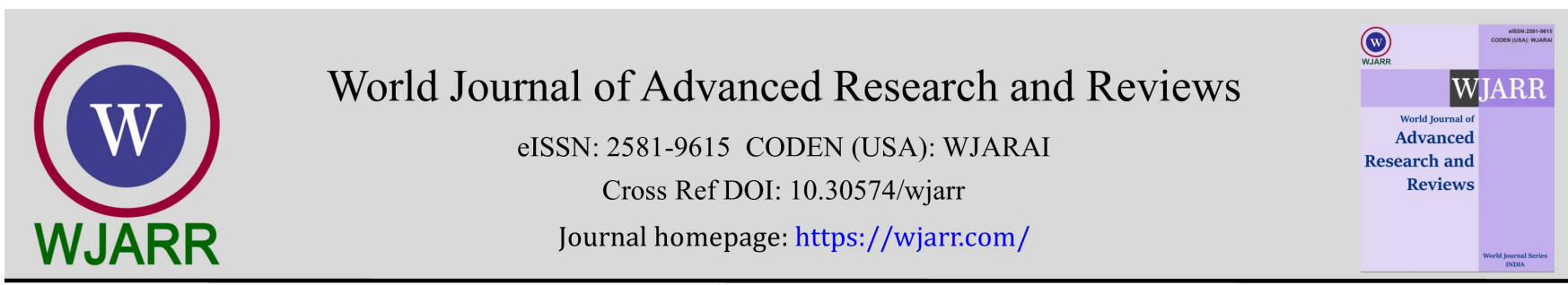

(RESEARCH ARTICLE)

\title{
Judicious and non-judicious use of cephalexin antibiotic in indoor poultry experimentation and detection of cephalexin residues in edible poultry tissues
}

\author{
DM Nazmul Hossain, Md Shafiqul Islam *, Md Rakibul Hasan, Md Anaruzzaman and Kazi Rafiqul Islam \\ Department of Pharmacology, Faculty of Veterinary Science, Bangladesh Agricultural University, Mymensingh-2202, \\ Bangladesh.
}

World Journal of Advanced Research and Reviews, 2021, 09(03), 288-296

Publication history: Received on 09 February 2021; revised on 11 March 2021; accepted on 14 March 2021

Article DOI: https://doi.org/10.30574/wjarr.2021.9.3.0101

\begin{abstract}
Antibiotics are the most widely injudiciously used drugs for therapeutic purposes throughout the world. This study aimed to detect cephalexin residue after discriminate and indiscriminate administration of cephalexin antibiotic in broiler. Eighteen broiler chicks, DOC (Cobb-500) were collected \& reared for up to 31 days. The chicks were randomly divided into three groups namely control group (Group-A), discriminate cephalexin group (Group-B) and indiscriminate cephalexin group (Group-C). Each group consists of 6 birds. In this investigation, only a detectable level of antibiotic residues was found in indiscriminate group of poultry. A total of 72 samples were investigated by the TLC method. The overall residue of cephalexin found in indiscriminate group as in liver (100\%), kidney (83.33\%), thigh muscle (25.00\%), breast muscle (8.33\%), fat and spleen (66.67\%) respectively. The final average body weight were recorded highest in indiscriminate antibiotic group (1804.17 $\pm 73.92 \mathrm{gm})$ followed by discriminate group $(1741.33 \pm 63.63 \mathrm{gm})$ and control group $(1453.33 \pm 26.39 \mathrm{gm})$. The body weight was found significantly $(\mathrm{p}<0.05)$ higher in the antibiotic treated groups. The hematological parameters such as $\mathrm{Hb}, \mathrm{PCV}$ and TEC values of treatment groups showed significantly $(\mathrm{p}<0.05)$ lower, while PCV did not show any significant difference compared to the control group. Overall, the present study documented the widespread abuse of cephalexin and failure to implement the recommended withdrawal period will undeniably lead to deposition of residues in broiler tissues.
\end{abstract}

Keywords: Antibiotic residues; Broiler; Thin layer chromatography; Cephalexin

\section{Introduction}

Antibiotics are used widely in the poultry industry as therapeutic, prophylactic and growth promoters [1]. Antibiotics are used in required for efficient production of poultry products such as eggs and meat. Antibiotics improve growth rate, increase feed utilization, reduce mortality and morbidity. Antibiotics also help to prevent and treat diseases [2]. So antibiotics are directly used in poultry production for different purposes [3]. But indiscriminate use of antibiotics causes deposition of antibiotic residues in the edible tissues of poultry [4]. Antibiotic residues result in antibiotic resistance, toxicity, teratogenicity, carcinogenicity and different public health problem associated with hypersensitivity reaction [5].

Cephalexin is used in the treatment of different bacterial infections. Cephalexin is effective against most gram-positive cocci. Additionally, cephalexin also works against gram-negative bacteria, particularly E. coli, Klebsiella pneumonia [6]. Cephalexin is also commonly used in treatment of streptococcal and staphylococcal infections [7]. Despite the important therapeutic use of cephalexin in veterinary practices and public health issue, relatively little has been known about residual status of this drug in broiler. Therefore, the goal of the indoor trial research was to detect the residue of Cephalexin antibiotic in edible poultry tissue if any

\footnotetext{
* Corresponding author: Dr. Md. Shafiqul Islam

Department of Pharmacology, Faculty of Veterinary Science, Bangladesh Agricultural University, Mymensingh-2202, Bangladesh. 


\section{Material and methods}

\subsection{Experimental design}

18 day-old broiler chicks (Cobb-500) were brought from the hatchery of CP Bangladesh Company Limited, valuka, Mymensingh for experimental study. Day old chicks were supplied with fresh drinking water containing glucose and vitamin C to remove stress. One hour later readymade broiler starter feed was given to the chicks. The feed was collected from the Authorized dealer of the Quality Feeds Limited, Mymensingh. The chicks were divided randomly in control group (Group A), discriminate group (Group B) and indiscriminate group (Group C). At day 16th (Cephalexin Monohydrate BP) antibiotic was supplied in the drinking water @ 2g per liter. Group B and C were supplied antibiotic medicated water and group A was left as untreated group. In group B a withdrawal period of 7 days was maintained, but in group C no withdrawal period was maintained.

\subsection{Sample collection}

On day 31, before sacrifice; all the birds of three groups (Group- A, B and C) were weighed individually and the results were recorded. After slaughtering of the birds, the breast muscle, thigh muscle, kidney and liver were collected for the estimation of antibiotic residue. All samples were marked separately and preserved at $-20^{\circ} \mathrm{C}$ in polythene bags for their extraction and analysis. Blood samples were also collected and preserved for hematological analysis.

\subsection{Sample preparation}

Experimental samples such as muscle tissue, liver and kidney were macerated with mortar and pestle. Samples were prepared as described by Islam et al. [8]. 4gm of each samples were taken and homogenized with $10 \mathrm{ml}$ phosphate buffer ( $\mathrm{pH}$ 7.2), $2 \mathrm{ml}$ tricholoracetic acid (30\%) was added carefully, mixed and then centrifuged. Supernatant was collected properly and same volume of diethyl ether mixed and kept for 15 minutes and upper oily portion was discarded. The lower aliquot was evaporated until dryness and reconstituted with mobile phase solutions (Methanolacetone). The prepared sample was kept into refrigerator for further experimentation.

\subsection{Thin layer chromatography (TLC)}

\subsubsection{TLC apparatus}

TLC was done with few modification described by Tajick and B Shohreh [9]. Used apparatus were thin layer chromatography pate, mobile phase tank, TLC detection chamber and other necessary instruments. . In this experiment, standard antibiotics were used to identify the residues of antibiotics [10]. Spots were visualized in UV detection box at $256 \mathrm{~nm}$ and the outlines of the spots were marked with a series of dots using sharp pencil for calculation of retention factor (Rf).

\subsection{Statistical analysis}

Statistical analysis was performed by one way ANOVA using Graphpad Prism; version 6. The results were expressed as mean \pm standard error mean (S.E.M).

\section{Results}

\subsection{Live body weight of broilers at different stages of the age}

At the beginning of the supply of cephalexin antibiotic with drinking water, the body weight among the different groups of broilers did not show any significant difference. However, after 7 days, the body weight of group-B and group-C increased markedly compared with the body weight of group-A. On day 28th and day 31st the body weight of two treatment groups showed significant difference $(\mathrm{P}<0.05)$ compared with the body weight of control group (Table-1). 
Table 1 Body weight of broilers at different age

\begin{tabular}{|c|c|c|c|c|c|}
\hline \multirow[t]{2}{*}{ Day } & \multicolumn{3}{|c|}{ Live Body Weight $(g)($ Mean \pm SEM) } & \multirow[t]{2}{*}{ P Value } & \multirow{2}{*}{$\begin{array}{l}\text { Level of } \\
\text { significa } \\
\text { nce }\end{array}$} \\
\hline & Group-A & Group-B & Group-C & & \\
\hline $16^{\text {th }}$ Day & $573.67 \pm 18.33$ & $561.33 \pm 27.15$ & $561.50 \pm 9.26$ & 0.88 & NS \\
\hline $22^{\text {th Day }}$ & $923.00 \pm 16.83$ & $1057.67 \pm 38.94^{* *}$ & $1051.83 \pm 30.40^{* *}$ & 0.01 & $* *$ \\
\hline $28^{\text {th }}$ Day & $\begin{array}{l}1261.83 \quad \pm \\
19.17\end{array}$ & $1473.33 \pm 49.34^{* *}$ & $1551.33 \pm 48.35^{*}$ & 0.01 & $* *$ \\
\hline $31^{\text {st }}$ Day & $1453.33 \pm 26.39$ & $1741.33 \pm 63.63^{* *}$ & $1804.17 \pm 73.92^{* *}$ & 0.01 & $* *$ \\
\hline
\end{tabular}

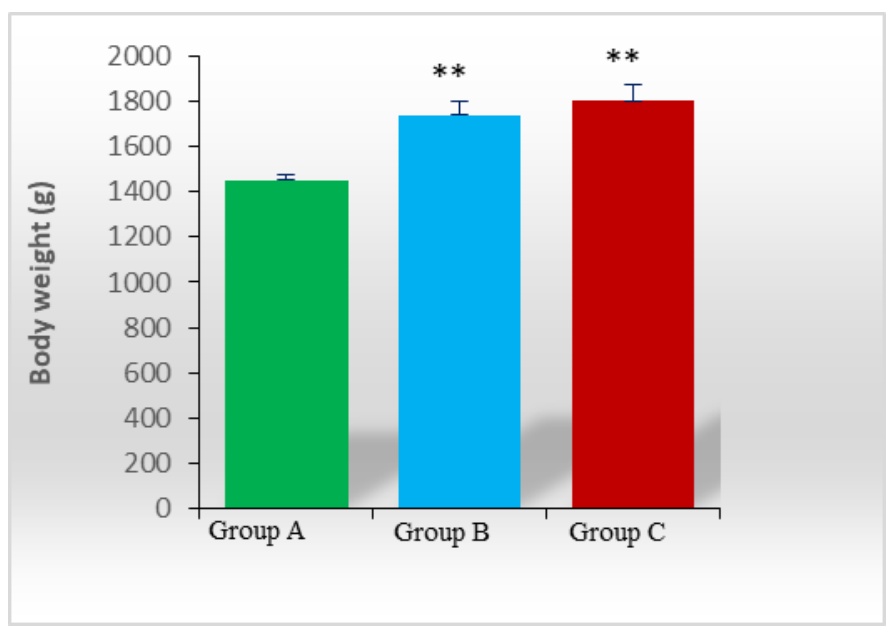

Figure 1 Body weight on 31st day

\subsection{Determination of different hematological parameters of broiler}

Statistical analysis (Table-2) of different hematological parameters on 31st day showed highly significant difference (P $<0.05$ ) in case of hemoglobin ( $\mathrm{Hb}$ ) and total erythrocyte count (TEC) among the three groups of broilers. But in case of packed cell volume (PCV) among the three groups (Group- A, B and C) did not show any significant difference $(\mathrm{P}<0.05)$.

Table 2 Different hematological parameters of Broiler

\begin{tabular}{|c|c|c|c|c|c|}
\hline \multirow[t]{2}{*}{ Blood Parameter } & \multicolumn{3}{|c|}{$\begin{array}{l}\text { Average blood parameters value } \\
(\text { Mean } \pm \text { SEM) }\end{array}$} & \multirow[t]{2}{*}{$\begin{array}{l}\text { P } \\
\text { Value }\end{array}$} & \multirow{2}{*}{$\begin{array}{l}\text { Level of } \\
\text { signific } \\
\text { ance }\end{array}$} \\
\hline & Group-A & Group-B & Group-C & & \\
\hline $\mathrm{Hb}(\mathrm{g} / \mathrm{dl})$ & $8.17 \pm 0.07$ & $7.25 \pm 0.10^{* *}$ & $6.17 \pm 0.07^{* *}$ & $<0.01$ & $* *$ \\
\hline PCV (\%) & $24.17 \pm 0.48$ & $22.00 \pm 0.73$ & $20.00 \pm 0.97$ & 0.35 & NS \\
\hline TEC (million $/ \mathrm{mm}^{3}$ ) & $3.20 \pm 0.06$ & $2.76 \pm 0.03^{* *}$ & $2.18 \pm 0.07^{* *}$ & $<0.01$ & $* *$ \\
\hline
\end{tabular}




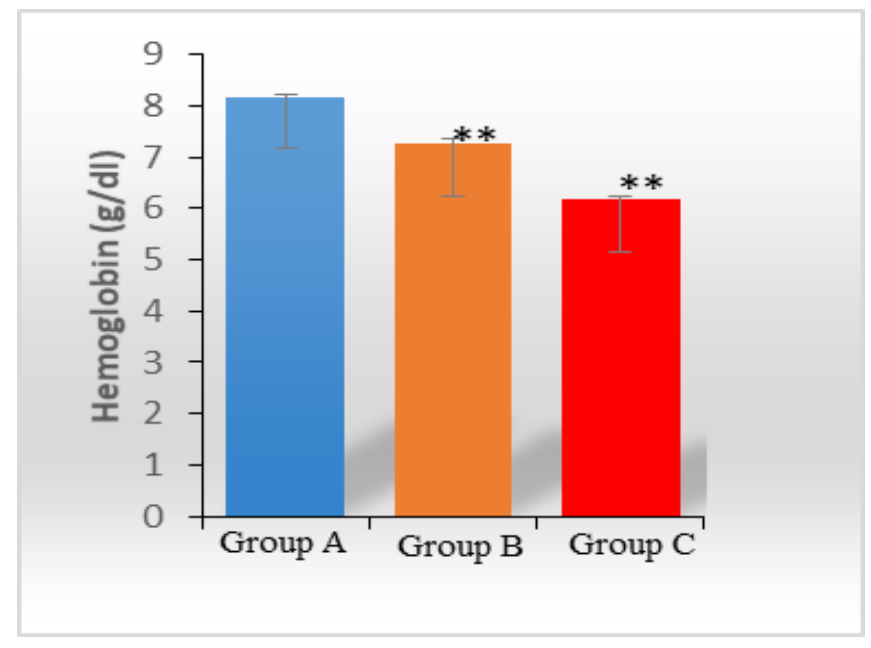

Figure $2 \mathrm{Hb}$ estimation

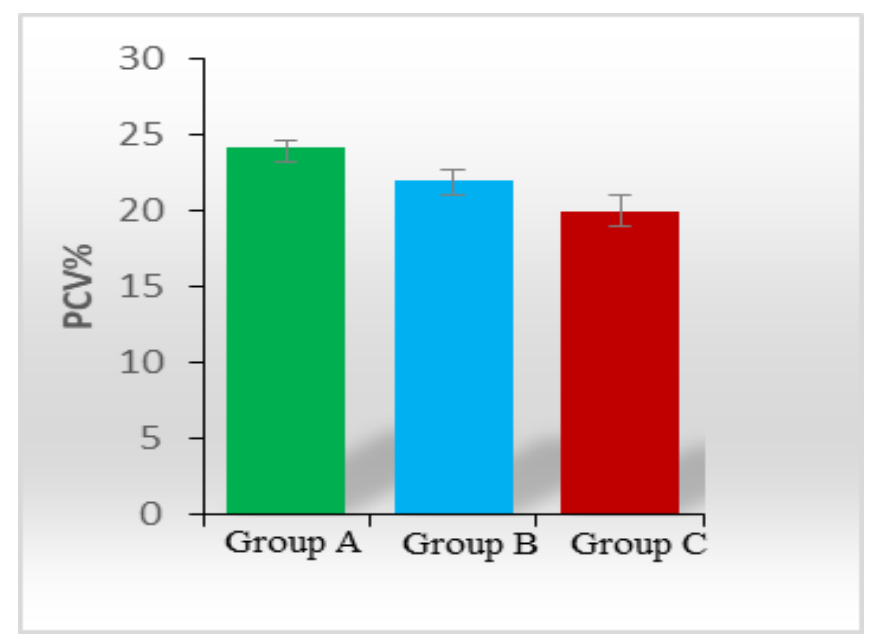

Figure 3 Determination of Packed cell volume

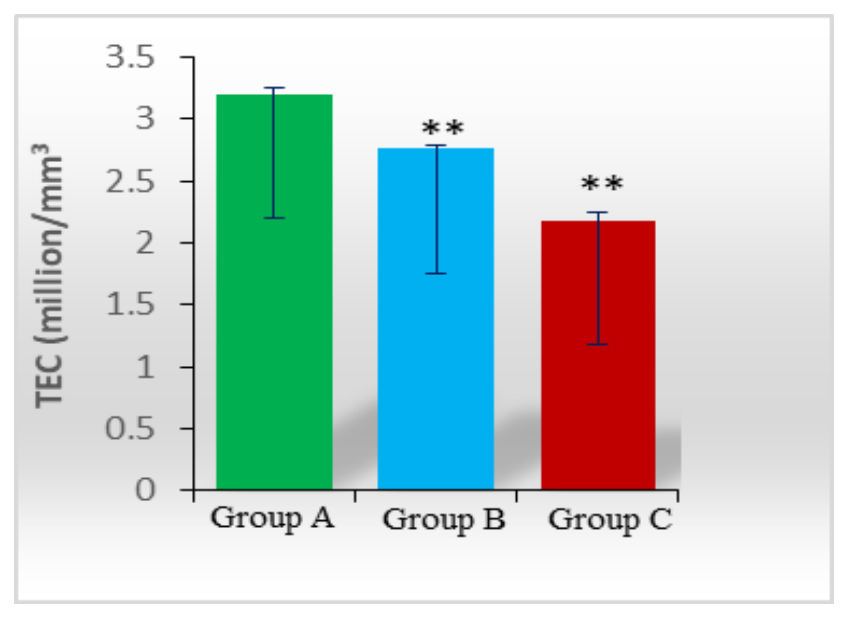

Figure 4 Total erythrocyte count 


\subsection{Detection of cephalexin antibiotic residues in edible tissue of broiler}

Cephalexin is an important and most useful antibiotic in poultry industry. It can be used as alternative to penicillin. This drug is very much effective against respiratory, urinary infections and many more. In this regard, cephalexin is now widely used in large animal, laying hens and also in broiler production. But the main problem now is arising due to the long-term and indiscriminate use of this antibiotic as it tends to accumulate in the edible tissue, bones, fat and other soft organs like liver, kidney, spleen etc. Eating of these products might cause various health hazards in human. The present study was designed to detect the antibiotic residues in broiler meat and giblets. The indoor study revealed that, in discriminate antibiotic group (Group-B) 100\% liver samples, $66.67 \%$ kidney, $16.67 \%$ thigh muscle and $33.33 \%$ fat and spleen samples were positive whereas the residue was absent in the breast muscle samples. Overall results in the discriminate antibiotic group showed that, among in the total of 36 samples, $41.67 \%$ (15) samples were positive (Table3). In indiscriminate antibiotic group (group-C) all the samples were positive in case of liver, kidney, fat and spleen samples. Only $33.33 \%$ and $16.67 \%$ samples were positive in case of thigh muscle and breast muscle samples. A total of 27 (75.00\%) samples were positive in that group (Table-4). In (Table-5), among all the 72 samples, 42 (58.33\%) samples were positive for the presence of cephalexin antibiotic residue in thin layer chromatography plate under UV detector.

Table 3 Percentage (\%) of cephalexin antibiotic residue in different samples of group-B (Discriminate antibiotic group) through TLC

\begin{tabular}{|l|l|l|l|l|l|}
\hline Name of Sample & \multirow{2}{*}{$\begin{array}{l}\text { Total No. } \\
\text { of }\end{array}$} & \multicolumn{2}{l|}{ No. of sample } & \multicolumn{2}{l|}{ \% of sample } \\
\cline { 3 - 6 } & Sample & Positive & Negative & $\begin{array}{l}\text { Positive } \\
\text { (\%) }\end{array}$ & Negative (\%) \\
\hline Liver & 6 & 6 & 0 & 100 & 0.00 \\
\hline Kidney & 6 & 4 & 2 & 66.67 & 33.33 \\
\hline Thigh muscle & 6 & 1 & 5 & 16.67 & 83.33 \\
\hline Breast muscle & 6 & 0 & 6 & 0.00 & 100 \\
\hline Fat & 6 & 2 & 4 & 33.33 & 66.67 \\
\hline Spleen & 6 & 2 & 4 & 33.33 & 66.67 \\
\hline Total & 36 & 15 & 21 & 41.67 & 58.33 \\
\hline
\end{tabular}

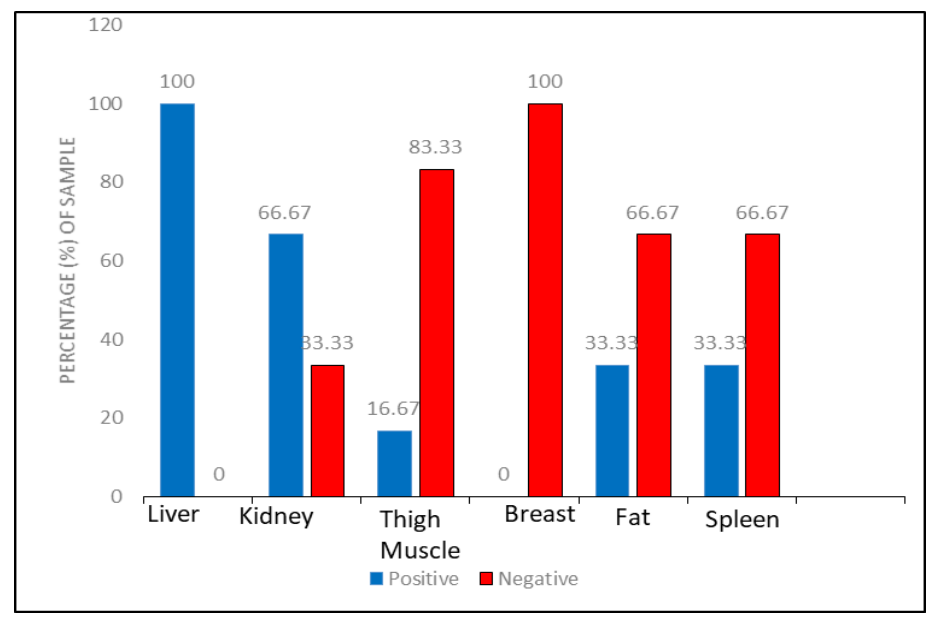

Figure 5 Cephalexin antibiotic residue in discriminate group. 
Table 4 Percentage (\%) of cephalexin antibiotic residue in different samples of group-C (Indiscriminate antibiotic group) through TLC

\begin{tabular}{|l|l|l|l|l|l|}
\hline \multirow{2}{*}{$\begin{array}{l}\text { Name } \\
\text { sample }\end{array}$} & $\begin{array}{l}\text { Total no. } \\
\text { of sample }\end{array}$ & \multicolumn{2}{|l|}{ No. of sample } & \multicolumn{2}{l|}{ \% of sample } \\
\cline { 5 - 6 } & & Positive & $\begin{array}{l}\text { Negativ } \\
\text { e }\end{array}$ & $\begin{array}{l}\text { Positive } \\
\text { (\%) }\end{array}$ & $\begin{array}{l}\text { Negative } \\
\text { (\%) }\end{array}$ \\
\hline Liver & 6 & 6 & 0 & 100 & 0.00 \\
\hline Kidney & 6 & 6 & 0 & 100 & 0.00 \\
\hline Thigh muscle & 6 & 2 & 4 & 33.33 & 66.67 \\
\hline Breast muscle & 6 & 1 & 5 & 16.67 & 83.33 \\
\hline Fat & 6 & 6 & 0 & 100 & 0.00 \\
\hline Spleen & 6 & 6 & 0 & 100 & 0.00 \\
\hline Total & 36 & 27 & 9 & 75.00 & 25.00 \\
\hline
\end{tabular}

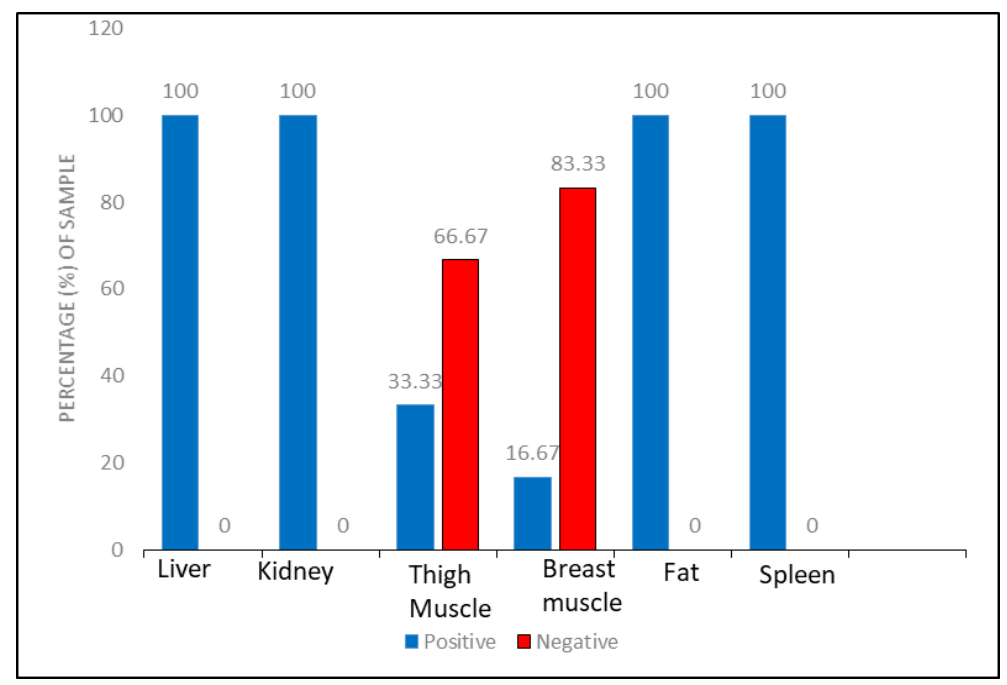

Figure 6 Cephalexin antibiotic residue in indiscriminate group

Table 5 Over all percentage (\%) of cephalexin antibiotic residue in different samples of broiler

\begin{tabular}{|l|l|l|l|l|l|}
\hline \multirow{2}{*}{ Name of Sample } & \multirow{2}{*}{$\begin{array}{l}\text { Total No. } \\
\text { of Sample }\end{array}$} & No. of sample & \% of sample \\
\cline { 3 - 6 } & & Positive & Negative & Positive (\%) & $\begin{array}{l}\text { Negative } \\
\text { (\%) }\end{array}$ \\
\hline Liver & 12 & 12 & 0 & 100 & 0.00 \\
\hline Kidney & 12 & 10 & 2 & 83.33 & 16.67 \\
\hline Thigh muscle & 12 & 3 & 9 & 25.00 & 75.00 \\
\hline Breast muscle & 12 & 1 & 11 & 8.33 & 91.67 \\
\hline Fat & 12 & 8 & 4 & 66.67 & 33.33 \\
\hline Spleen & 12 & 8 & 4 & 66.67 & 33.33 \\
\hline Total & 72 & 42 & 30 & 58.33 & 41.67 \\
\hline
\end{tabular}




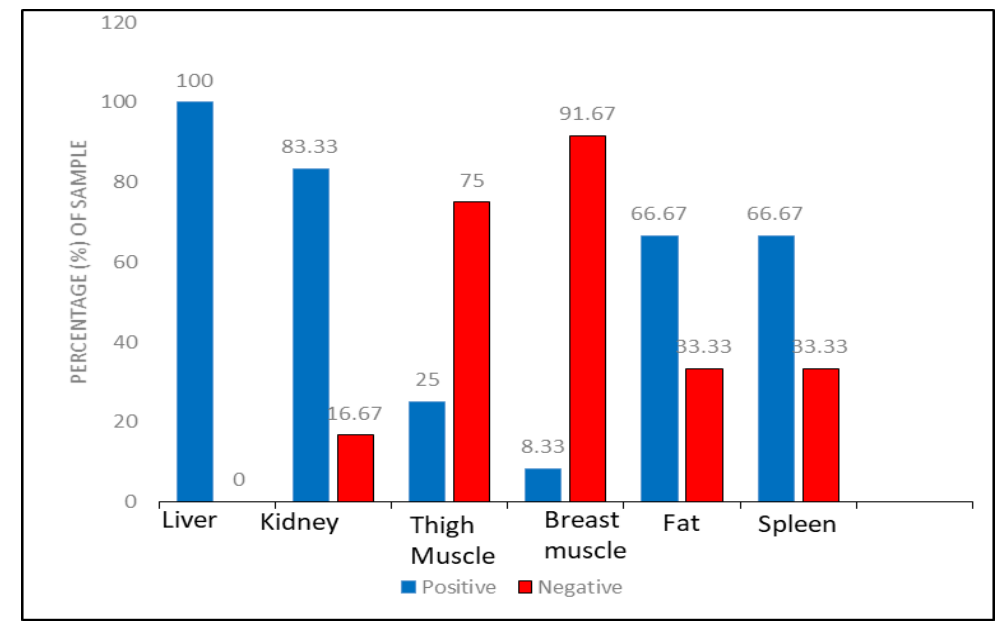

Figure 7 Over all Cephalexin antibiotic residues.

\section{Discussion}

Recently, a good number of studies have been carried out to investigate the presence of the different veterinary drugs including antibiotic residues in animal products $[11,12,13,14,15]$. The main objective of this study was to screen for the presence of antibiotic residues in poultry meat as well as to know about the growth performance and changes in the hematological parameters.

Body weight was measured on a weekly basis. On day 16, almost similar body weights were observed in all groups (Table-1). On day 31st, the highest body weight was observed in group-C (indiscriminate antibiotic group) and lowest in group-A (Control group) $[11,12,13,14]$. Differences among the two-antibiotic treated group and control group were observed. However, Body weight enhanced significantly $(\mathrm{p}<0.05)$ in both treatment group (group-B \& C) compared to control group $[11,12,13,14,15,16,17]$. Although the mechanism by which antibiotics work as a growth promoter yet not defined; however, different studies have indicated the antimicrobial activities of antibiotics against pathogens and harmful bacteria promoting overall growth [5].

Analysis of hematological parameters showed quantitative changes in some blood indices of broiler were observed under a prolonged exposure to indiscriminate and therapeutic concentrations of cephalexin antibiotic. There was established a marked change in the hemoglobin level and in the number of total erythrocyte count towards reduction (Table-2) in the case of cephalexin antibiotic $(\mathrm{P}<0.01)$ in discriminate antibiotic group (Group-B) \& indiscriminate antibiotic group (group-C) compared with the control group (group-A) whereas the packed cell volume did not show any significant changes $[12,13,15,18]$.

Detection of cephalexin antibiotic residues by using TLC method showed that overall 58.33\% samples were positive compared to $41.67 \%$ that were negative (Table-6). Since our research is an indoor trial, the highest amount of cephalexin residues were deposited in the liver and kidney $100 \%$ and $83.33 \%$ respectively $[19,20]$. The lowest amounts of residues were deposited in the thigh muscle and breast muscle $25.00 \%$ and $8.33 \%$ respectively [21, 22]. In discriminate group (Table-3) of broiler, antibiotic residues were also found in liver $100 \%$, kidney $83.33 \%$ and in fat $66.67 \%$ whereas residue was absent in breast muscle. Since the liver is the main metabolizing organ as well as the kidney is the main excretory organ and the antibiotics also tends to deposit in fat, so these organs remain some antibiotic residue even after maintaining a successful withdrawal period. However, the main reason for antibiotic residues in edible tissue is the inappropriate use of antibiotics, besides the withdrawal period is not maintained properly [23].

Although the indoor trial study indicated that, antibiotic residues are found in the liver and in kidney even after maintaining a successful withdrawal period for the respective antibiotic, but the good news is that after maintaining a successful withdrawal period, the antibiotics are almost absent in the muscles of thigh and breast 


\section{Conclusion}

The present study was conducted to figure out the presence of cephalexin antibiotic residue in the edible tissue of broiler and offal's. Since it was an indoor investigation, so the main goal of this research was to detect the antibiotic in the muscle tissue even after maintaining a successful withdrawal period. Body weights of two groups of broilers showed highly significant changes during the use of antibiotic compared with the control group. Among the blood parameters the hemoglobin and the total erythrocyte showed significant difference whereas the packed cell volume did not show any significant changes. Percentage for positive samples, data was collected through the detection by TLC screening. The data obtained from the analyzed samples showed that, among the total of 72 samples, 42 (58.33\%) samples were positive and 30 samples (41.67\%) found negative. Great numbers of samples were positive in case of liver and kidney, $100 \%$ and $83.33 \%$ respectively. On the other hand, the thigh muscle samples were found less positive, $25.00 \%$ whereas the breast muscle showed only $8.33 \%$ positivity. Great numbers of samples were found with antimicrobial residues. Most of the farmers are not aware of bio-security, they do not maintain withdrawal period properly resulting antibiotic residues in edible tissue. Antimicrobial resistant bacteria in food animals can affect not only animal health, but also public health when they enter the food chain. National authorities should adopt a proactive approach that promotes programs aimed at reducing the need for antimicrobials in food animals and ensuring their prudent use.

Further investigation is required for the quantitative determination of antibiotic residues in edible tissue of broiler. Over all this indoor investigation research will be a milestone on the way of the importance of maintaining a withdrawal period while producing food animal for human consumption and also creating the awareness about the residual hazards of antibiotic on human health that comes from the food animals.

\section{Compliance with ethical standards}

\section{Acknowledgments}

This work was supported by the Ministry of Education, Government of the People's Republic of Bangladesh by a grant in research. (Project No. 37.20.0000.004.033.020.2016.1053; LS2019925).

\section{Disclosure of conflict of interest}

The authors state no conflict of interest.

\section{Statement of ethical approval}

The experimental broilers were used ethically and at the end of the experiment sacrificed humanely following the ethical and welfare guidelines set by the Animal Welfare and Experimental Ethics Committee of Bangladesh Agricultural University [approval number: AWEEC/ BAU/2021(09)].

\section{References}

[1] Oluwasile B, Agbaje M, Ojo 0, Dipeolu M. Antibiotic usage pattern in selected poultry farms in Ogun state. Sokoto Journal of Veterinary Sciences. 2014; 12(1): 45-50.

[2] Cromwell GL. Why and how antibiotics are used in swine production. Animal Biotechnology. 2002; 13(1): 7-27.

[3] Mund MD, Khan UH, Tahir U, Mustafa BE, Fayyaz A. Antimicrobial drug residues in poultry products and implications on public health: A review. International Journal of Food Properties. 2017; 20(7): 1433-1446.

[4] Butaye P, Devriese LA, Haesebrouck F. Antimicrobial growth promoters used in animal feed: Effects of less wellknown antibiotics on gram- positive bacteria. Clinical Microbiology Reviews. 2003; 16(2): 175-188.

[5] Darwish WS, Eldaly EA, El-Abbasy MT, Ikenaka Y, Nakayama S et al. Antibiotic residues in food: the African scenario. Japanese Journal of Veterinary Research. 2013; 61: 13-22.

[6] Bailey A, Walker A, Hadley A, James DG. Cephalexin-a new oral antibiotic. Postgraduate Medical Journal. $1970 ; 46$ (533): 157-8.

[7] Derrick CW, Reilly K. The role of cephalexin in the treatment of skin and soft-tissue infections. Postgraduate Medical Journal. 1983; 59(5): 43-6. 
[8] Islam MS, Islam MZ, Islam MS. Discriminate and indiscriminate use of amoxicillin and its effects on hematological parameters of broiler. Asian Journal of Medical and Biological Research. 2019; 5(2): 153-157.

[9] Tajick MA and Shohreh B. Detection of antibiotics residue in chicken meat using TLC. International Journal of Poultry Science. 2006; 5 (7): 611-612.

[10] Thangadu S, Shukla SK, Anjaneyulu Y. Separation and detection of certain $\beta$ - lactams and floroquinolone antibiotic drugs by thin layer chromatography. Analytical Sciences. 2002; 18(1): 97-101.

[11] Ali MR, Sikder MMH, Islam MS, Islam MS. Investigation of discriminate and indiscriminate use of doxycycline in broiler: an indoor research on antibiotic doxycycline residue study in edible poultry tissue. Asian Journal of Medical and Biological Research. 2020; 6(1): 1-7.

[12] Das D, Islam MS, Sikde MMH, Alom F, Sharmin MA, Ashraf MZF. Presence of antibiotic residue and residual effect of tylosin tartrate in broiler. International Journal of Natural and Social Sciences. 2020; 7(2): 29-35.

[13] Islam MS, Islam MZ, Islam MS. Discriminate and indiscriminate use of amoxicillin antibiotic and detection of its residue in poultry edible tissue by thin layer chromatography (TLC) method. Asian-Australasian Journal of Food Safety and Security. 2019; 3(2): 96-102.

[14] Shumiya MK, Das D, Sharmin MA, Ashraf MZF, Das S, Tuhin MRI, Islam MS. Residual effect of amoxicillin in broiler. International Journal of Natural and Social Sciences. 2020; 7(3): 51-58.

[15] Haque MI, Ahmad N, Miah MA. Comparative analysis of body weight and serum biochemistry in broilers supplemented with some selected probiotics and antibiotic growth promoters. Journal of Advanced Veterinary and Animal Research. 2017; 4(3): 288-294.

[16] Lakshmi R, Nusrin KS, Ann GS, Sreelakshmi KS. Role of betalactamases in antibiotic resistance: Review. International Research Journal of Pharmacy. 2014; 5(2): 37-40.

[17] Marshall BM, Levy SB. Food animals and antimicrobials: impacts on human health. Clinical Microbiology Reviews. 2011; 24(4): 718-733.

[18] Slyamova1 A, Sarsembayeva N, Valdovska A, Micinski J, Ussenbayev A et al. Effects of antibiotic growth promoters on biochemical and haematological parameters of broiler chickens' blood. Research for Rural Development. 2016; 1: 131-136.

[19] Salehzadeh F, Madani R, Salehzadeh A, Rokni N and Golchinefar F. Oxytetracycline residue in chicken tissues from Tehran slaughterhouses in Iran. Pakistan journal of nutrition. 2006; 5(4): 377-381.

[20] Shahid MA, Siddique M, Abubakar M, Arshed MJ, Asif M et al. Status of oxytetracycline residues in chicken meat in Rawalpindi, Islama- bad area of Pakistan. Asian Journal of Poultry Sciences. 2007; 1(1): 8-15.

[21] Hakem A, Titouche Y, Houali K, Yabrir B, Malki O et al. Screening of Antibiotics Residues in Poultry Meat by Microbiological Methods. Bulletin of the University of Agricultural Sciences and Veterinary Medicine Cluj-Napoca. Veterinary Medicine. 2013; 70(1): 77-82.

[22] Sattar S, Hassan MM, Islam SKMA, Alam M, Faruk S. Antibiotic residues in broiler and layer meat in Chittagong district of Bangladesh. Veterinary World. 2014; 7(9): 738-743.

[23] Hussein MA, Khalil S. Screening of some antibiotics and anabolic steroids residues in broiler fillet marketed in ElSharkia Governorate. Life Science Journal. 2013; 10(1): 2111-2118. 